\title{
IMPROVING SKILLS \\ TO TEACH STATISTICS IN SECONDARY SCHOOL THROUGH ACTIVITY-BASED WORKSHOPS
}

\author{
MARÍA SOLEDAD FERNÁNDEZ \\ Universidad de Buenos Aires \\ sfernandez79@gmail.com \\ CARLOS POMILIO \\ Universidad de Buenos Aires \\ carlosjpomilio@gmail.com \\ GERARDO CUETO \\ Universidad de Buenos Aires \\ gercueto@gmail.com \\ JULIETA FILLOY \\ Universidad de Buenos Aires \\ julietafilloy@gmail.com
ADELIA GONZALEZ-ARZAC
Universidad de Buenos Aires
agoarzac@agro.uba.ar \\ JIMENA LOIS-MILEVICICH \\ Universidad de Buenos Aires \\ jime.loism@bg.fcen.uba.ar \\ ADRIANA PÉREZ \\ Universidad de Buenos Aires \\ adrianaperez000@gmail.com
}

\begin{abstract}
Though statistics is covered in secondary-school curricula, it is usually limited to few lessons and mainly taught in a procedural approach. There seems to be a gap between the education of mathematics teachers and the demands on their practice. Learning statistics from a mathematical perspective does not qualify to teach the subject properly. Therefore, we developed a pedagogical intervention that consists in a training program for teaching aimed at mathematics pre-service teachers and focused on activity-based learning. Two workshops and a web-site were designed: first, to improve competencies in teaching statistics at secondary level, and second, to positively influence attitudes towards statistics. Workshops about descriptive statistics and probability were focused on real-data analysis from media, games, and simulations. Over several years, more than 500 teachers attended these workshops, which were positively evaluated in terms of content, relevance, and applicability. A follow-up survey 2-5 years later showed that most teachers are teaching statistics in their classes, which can be seen as great step forward to bring statistics into the classroom.
\end{abstract}


Keywords: Statistics education research; Pre-service teacher training; Statistical literacy; Descriptive Statistics and Probability Workshops

\section{INTRODUCTION}

The aim of the paper is to describe a teacher training program in Argentina for pre-service teachers at teacher training institutes. The way this program was administered should help to fill the current gap in the didactic training of future teachers and to influence their later teaching as well as their attitudes towards statistics. Both factors would have a positive impact on the education in statistics and probability for future generations of high-school students.

\subsection{STATISTICAL LITERACY, REASONING, AND THINKING}

Statistical literacy implies the ability of reading and interpreting data with a critical stance using statistics as a source of valid evidence (Garfield \& Ben-Zvi, 2004). To achieve this, a basic understanding of the statistical language, its symbols and the reading and interpretation of graphics, as well as the basic logic of this discipline is necessary (Batanero \& Borovcnik, 2016). Several authors also agree that statistical literacy includes the interpretation of phenomena in the contexts where the information is embedded (see Borovcnik, 2016). In an increasingly datadriven world, statistical literacy, reasoning, and thinking has become an essential competency for citizens in order to make or understand social, economic, and political decisions based on data (Ben-Zvi \& Garfield, 2004). Besides, these skills should not only seek that citizens have a better understanding of the society where they live, but that also contribute to its transformation (Pinto et al., 2017).

Statistics education is contained in secondary-school curricula, but in many countries including Argentina - it is usually limited to few lessons and is mainly taught in a procedural approach (Batanero \& Díaz, 2010, Meletiou, 2007). There is substantial evidence that both preservice and in-service mathematics teachers usually do not receive the educational tools they need to teach statistical literacy, reasoning, and thinking (Batanero \& Díaz, 2010; Begg et al., 2004; Burrill \& Biehler, 2011; Lovett \& Lee, 2017).

To a large extent, the success of new curricular contents depends on the cooperativeness of mathematics teachers who are "the driving force of the reform in statistical education" (Ben-Zvi \& Makar, 2016). Statistical and pedagogical content knowledge (Callingham \& Watson, 2011; Groth, 2013) as well as a positive attitude towards statistics (Estrada, Batanero, \& Lancaster, 2011) are required for teaching of statistics to be successful.

\subsection{THE GAP IN STATISTICS EDUCATION OF MATHEMATICS TEACHERS}

While we consider the situation in Argentina, we see in the international discussion similar deficits in mathematics teachers' competencies in teaching statistics. The need to extend statistical literacy, thinking, and reasoning was taken into consideration in the curricular contents of secondary-school programs for mathematics courses in Argentina (Ministerio de Educación, 1993). An expected achievement is the development of critical thinking in the students, which involves analyzing and interpreting data, evidence, and different arguments to construct judgments and make consistent decisions. The curriculum includes the construction and interpretation of tables and graphs, descriptive statistics, and simple probability calculus. However, statistical contents are restricted to a few lessons, usually placed at the end of the course and frequently limited to basic procedural considerations (Kucukbeyaz \& Batto, 2012).

How is the training in statistics of mathematics teachers in Argentina? Secondary mathematics teachers attend a 4-year program (Profesorado) with only one 96-h course on probability and statistics, which covers the following topics: probability, random variables, 
probability distributions for discrete (Bernoulli, Binomial, Poisson) and continuous random variables (Uniform, Normal, Gamma, Normal), bivariate distributions, covariance, and correlation coefficient, Central Limit Theorem, descriptive statistics, point and interval estimation of a population mean, hypothesis test of a population mean. Although the contents are far-stretched, the training of statistics for mathematics teachers seems to focus entirely on the theoretical aspects of mathematical statistics rather than on statistical reasoning and thinking, which is expected for teaching the subject in the middle school. Furthermore, the training in statistical software is rather unusual. Although the curriculum includes a course on didactics of mathematics, the future mathematics teachers do not have a specific training on teaching statistics.

In this context, two main difficulties can be identified. Firstly, simply content knowledge of statistics is taught and apparently acquired; that means, the focus of teaching is on understanding the mathematical relations and their relevance for the statistical methods. Secondly, the future teachers lack pedagogical knowledge about teaching stochastics properly; that means, after the course, they are not able to react to difficulties students usually experience in learning the concepts and methods of probability and statistics. Middle-school mathematics textbooks also miss to provide adequate support. They are mainly focused on decontextualized and repetitive exercises based on the mere application of formulas and procedures (Pomilio et al., 2016). The situation is not better for the in-service teachers. The opportunities to access training in statistics, both in statistical and pedagogical content knowledge, after they are graduated, are very limited.

Fabrizio, López, and Plencovich (2011) investigated the results of a test on statistical knowledge taken by students from the last year of ten education programs for secondary mathematics teachers in Buenos Aires. The results showed that only $42 \%$ of the answers were correct, suggesting that the teacher students lack adequate content knowledge. In a similar way, Tauber, Cravero, and Redondo (2013) found that mathematics teachers had difficulties in the resolution of activities that imply statistical reasoning; those teachers could not apply the mathematics they learned to simple examples, neither were they able to provide suitable learning paths for their students.

\subsection{COGNITIVE AND NON-COGNITIVE ASPECTS OF TEACHING}

Teachers who have a weak content knowledge of statistical concepts do not feel confident to teach statistics as compared to other areas of mathematics and, accordingly, constrain their teaching to procedural aspects of statistics (Lovett \& Lee, 2017). Furthermore, as their teacher education missed to provide them with content and pedagogical content knowledge, once they stand in their class, they tend to teach their students in the same manner as they were instructed in their own school life. Thus, they transfer their beliefs about the deterministic nature of mathematics to statistics ignoring the stochastic nature of statistics (Meletiou, 2007).

Non-cognitive aspects, such as beliefs, emotions, and attitudes towards statistics are essential to be considered in teacher training as they can affect the learning and teaching of statistics. Negative attitudes towards statistics are related to low cognitive competence, and low motivation is caused by continuing instructional learning in statistics (Estrada, Batanero, \& Lancaster, 2011). By contrast, when teachers have good learning experiences, they develop positive attitudes and appreciate the value of statistics. As a consequence, they are willing to learn more on statistics and how to teach it and spend more time on teaching statistics in class (Estrada, Batanero, \& Fortuny, 2004; Lancaster, 2008). Therefore, beyond acquiring pedagogical content knowledge about probability and statistics, developing a positive attitude towards statistics becomes a main goal in the training of future mathematics teachers. 


\subsection{TO FILL THE GAP IN PEDAGOGIC KNOWLEDGE}

A key role in the ambitious project to build future generations of critical citizens is to encourage Argentinian mathematics teachers to teach statistics from a critical perspective, based on problem-solving skills and real-life contexts as it has been suggested by Wild and Pfannkuch (1999), Burrill and Biehler (2011), or Carver et al. (2016).

In order to fill the gap in statistical education of mathematics pre-service teachers, we have designed an intervention, which included a short training program to teach introductory statistics, and access to resources for teaching statistics. The intervention was administered by two workshops focused on activity-based learning; the goal was to develop statistical-reasoning skills in the participants (Carver et al., 2016; Franklin et al., 2015). A web-site was designed by our team to disseminate resources for statistics teaching. The project was embedded in the framework of a wider program of promoting the interaction between the university and the secondary school. By working together with secondary teachers, we intended to provide secondary-school graduates with better statistical-literacy competencies and to influence their attitudes towards statistics in a positive way.

\section{METHODOLOGY}

In this section, we describe the target population and the sample, and also the structure and content of the workshops and the web-site. Two surveys were administered on pre-service teachers: a post workshop opinion survey regarding the appropriateness of those workshops and their attitudes toward teaching statistics, and a follow-up survey, when they had finished their formation, regarding the perceived impact of the intervention.

\subsection{TARGET POPULATION AND SAMPLE}

The intervention was directed to students at public teacher-training institutes who studied to become mathematics teachers. The reasons that motivate us to work with this population were: future mathematics teachers are more accessible than in-service teachers, they are more susceptible to achieving attitudinal change, and the multiplier effect of the intervention will be possibly greater. Eight institutes from Buenos Aires were purposefully selected and agreed to participate in the study. In each participating institute, we contacted first the coordinator for mathematics education and then the instructor of the Probability and Statistics course. The students were in their third or fourth year of the secondary-teacher-education program for mathematics and had already approved the Probability and Statistics course. For a description of the course's content see Section 1.2.

\subsection{WORKSHOPS STRUCTURE}

Two workshops were developed following the GAISE (Guidelines for Assessment and Instruction in Statistics Education) framework (Franklin et al., 2007), which recommends activity-based learning environments for statistics learning. The workshops were designed following the structure implemented by others (such as Batanero \& Borovcnik, 2016); from the GAISE recommendations, we focused on teaching statistical thinking and conceptual understanding and integrated real data with a context and a purpose to foster active learning; we used technology to explore concepts and analyze data. The activities were designed in an attempt to accomplish at least two of the goals highlighted by the GAISE framework for students in introductory statistics courses:

1) Students should become critical consumers of statistically-based results reported in popular media, recognizing whether reported results reasonably follow from the study and analysis conducted; and 
2) Students should recognize and be able to explain the central role of randomness in designing studies and drawing conclusions (Carver et al., 2016).

The selection of activities in the workshops were inspired by the recommendations of Pfannkuch and Ben-Zvi (2011): developing the understanding of key statistical concepts, developing the ability to explore and learn from data, and developing statistical argumentation.

The workshops included part of the curricular contents in statistics and probability for secondary level in Argentina (Ministerio de Educación, 2011): data acquisition, samples and populations, tabular and graphical representation, descriptive statistics, randomness and probability. Each workshop included a single three-hour session and was delivered by professors, assistant teachers, and students of Biostatistics of the School of Exact and Natural Sciences of the University of Buenos Aires. Pre-service teachers were invited to voluntarily participate in both workshops, where they played the role of secondary students. At the end of each workshop, the pre-service teachers, their instructors, and the members of the staff discussed the activities and their applicability in the classroom, and an anonymous opinion survey was administered.

\subsection{CONTENT AND DESIGN OF WORKSHOP 1: MISLEADING NEWS}

Rationale. In the process of summarizing data, the information may - intentionally or not - be misrepresented or misinterpreted. Biased samples, inaccurate, wrongly scaled or otherwise misleading graphs, biased reference points or reference numbers for comparison and judgment, and misinterpretation of statistics are statistical errors that are frequently found in the news. We used these examples to draw the student's attention about the need of statistical literacy in order to detect manipulation in data presentation and to become a critical consumer of statisticallybased results reported in the media.

Topics. Sampling and inference, tabular and graphical presentation of data, measures of central tendency.

Materials. Activity sheet containing articles from newspapers, web-pages, etc.

Objective. To analyze real information provided by the mass media to recognize the misuse and any misleading conclusions or appreciate the advantage of using descriptive statistics.

Description. First, sample representativeness, measures of central tendency, and aspects of graphical representation were discussed avoiding formulas focusing on conceptual understanding of their use. Then, these concepts were contextualized with real data from newspapers or other sources. Published articles containing misleading graphs or percentages based on biased samples were discussed. For each example, we defined the sample and population, in order to identify non-random samples, or wrong inference (i.e., conclusions transferred to other populations). Emphasis was placed on how the choice of the statistics or the graph can lead to different conclusions or generate a different impact on readers. Finally, participants had to critically analyze a new set of newspaper articles and to check for potential statistical errors. This activity involved the following steps:

1. Participants were asked to form groups of two to four people.

2. Each group received a document with five news posted in different media (newspapers, $\mathrm{TV}$, web-sites). Each item consisted of graphics and/or text containing a conclusion that is supposed to be supported by statistical information (see. Figures 1 and 2).

3. Participants were encouraged to critically discuss the information provided within the group, identifying methodological errors (whether or not intentional) or biases that could affect the conclusion presented.

4. After identifying possible errors, each group had to propose methodological modifications in order to reach a correct conclusion. 


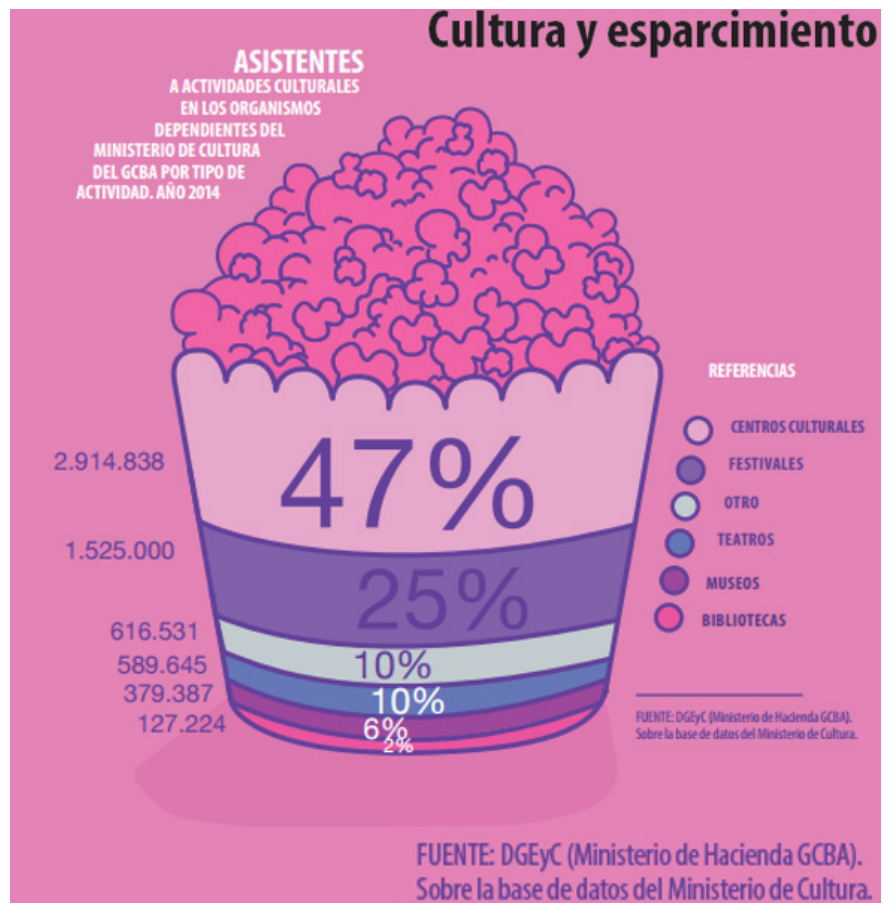

Figure 1. Misleading news in media: Pictogram with non-proportional frequencies

Source: www.estadisticaciudad.gob.ar/eyc/wp-content/uploads/2017/05/2017_05_buenosaires_en_numeros.pdf

三 MENú lanacion·com $\mid$ Cultura

Martes 12 de octubre de 2010 | Publicado en edición impresa

El dificil camino a la universidad

\section{El $43,7 \%$ de los jóvenes no decide qué carrera seguir}

Surge de una encuesta entre 5000 personas de entre 18 y 21 años; dificultades de orientación

Más notas para entender este tema

" Llega Expouniversidad

pocas semanas de abrirse el período de inscripciones en las universidades, un alto índice de jóvenes que quieren seguir estudios universitarios aún no decidieron qué carrera elegir.

"No tienen idea" de qué estudiar el 43,7 por ciento de 5000 jóvenes de entre 18 y 21 años y "no se deciden" el 41 por ciento de ellos. Los que "la tienen clara" con respecto a su futuro universitario representan un $15 \%$ de ellos.

Los datos que confirman la tendencia a posponer lo más posible una decisión tan importante provienen de una encuesta autoadministrada por los usuarios de www.quevasaestudiar.com.ar, un sitio de servicio y orientación.

Figure 2. News with wrong inference

Source: www.lanacion.com.ar/cultura/el-437-de-los-jovenes-no-decide-que-carrera-seguir-nid1313954 
5. After 20 minutes for discussion in groups, the participants were asked to expose their conclusions to other groups.

6. New examples provided by students from their experiences were shared and discussed.

7. A synthesis of good practices to consider in the presentation of statistical information was carried out to finish the task.

\subsection{WORKSHOP 2: PLACE YOUR BETS! ROULETTE BETTING STRATEGIES}

Rationale. Uncertainty is involved in many aspects of life. Instead of acting on hunches, uncertainty can be measured in order to make evidence-based decisions. Simulations are a useful tool for estimating probabilities and for developing an intuition about probabilistic reasoning. In this workshop, probabilities were calculated in the context of a game of chance; the participants were encouraged to calculate the probabilities to identify the most convenient choices, to understand intuitively their solutions, and to check this solution by simulation. This check-up should not only improve their competencies to find correct solutions but also to understand these solutions.

Topics. The topics were related to relative frequencies, patterns in long series of trials, convergence of stochastic processes, and probability calculations.

Materials. One roulette game was available for each group to allow for direct experience in order to check the appropriateness of various statements and strategies.

Objective. Investigate random processes in order to understand probability by detecting patterns in the results of a long series of trials. Develop participants' intuition about probabilistic reasoning.

Description. First, different games of chance and other games, in which luck is involved (roulette, bingo, dice game, football betting), were presented briefly in order to review concepts such as random events and probability. Then, participants were challenged to play roulette. This activity involved the following steps:

1. Participants were asked to form groups of $\sim 6$ people.

2. Within groups, each participant was asked to choose and always follow the same betting strategy in each turn of the roulette wheel. The betting strategies were:

Strategy \#1: only bet on single numbers;

Strategy \#2: only bet on rouge or noir;

Strategy \#3: only bet on dozens (twelve numbers as they are arranged on the roulette table, i.e., $1,4,7, \ldots ; 2,5,8, \ldots ; 3,6,9, \ldots)$;

Strategy \#4: only bet on odd or even;

Strategy \#5 only bet on zero;

Strategy \#6: only bet on columns.

3. Fifteen roulette rounds were carried out.

4. Each group was asked to register the winner for each round and to determine the total number of times, each one won.

5. The results obtained by all the groups were aggregated to calculate the chance of winning for each of the suggested betting strategy.

6. All six different betting strategies were ranked by the winning probability and the results were discussed.

7. Probabilities of each strategy were compared with the casino bets and payment table. The role of the zero was discussed. 


\subsection{WEB-SITE}

Our web-site (www.alternatistica.wordpress.com) was conceived as a platform to disseminate not only our workshops activities, but also to offer other resources for statistical teaching: more activities, further pedagogic resources, links, and references. We point out that, compared to the resources available in English; the online statistics-teaching resources in Spanish are very limited. The home page for the site is shown in Figure 3.

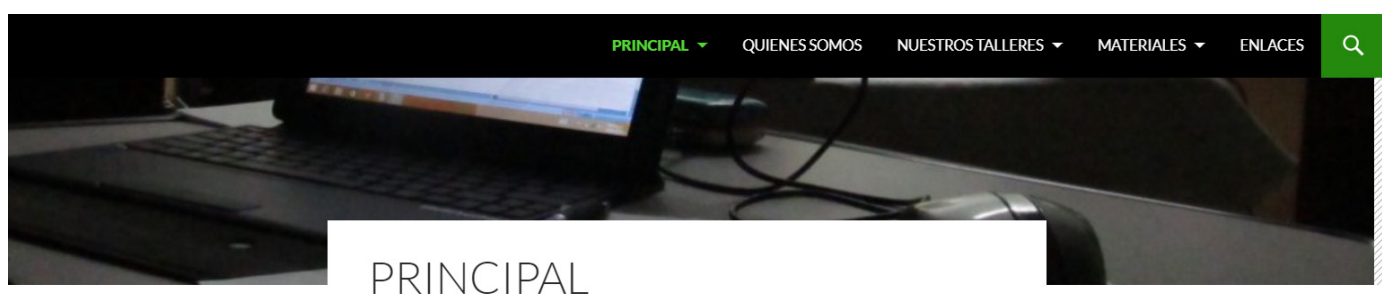

¡BIENVENIDO!

Alternativas Didácticas para la Enseñanza

de la Estadística

NOVEDADES:

¡NUEVOS RECURSOS DISPONIBLES! VISITÁ NUESTRA PÁGINA Y ACCEDÉA LOS NUEVOS RECURSOS EN ESPAÑOL

alternatisica@gmail.com

Figure 3. Homepage of the web-site for statistical teaching

\subsection{EVALUATION}

At the end of every workshop, the participants were encouraged to complete an anonymous and voluntary survey (opinion survey) to evaluate the workshop and their perceived attitudes towards statistics. In the first part, the survey included five statements, which had to be rated on a five-point Likert scale (judgments ranging from strongly disagree to strongly agree). In the second part of the survey, the participants were asked to rate the workshop on a scale of 1 to 10 where 1 was meant to signify really bad and 10 really good. Finally, an open-ended question asking for feedback and comments was included.

Two to five years after the workshop, the participants were contacted via e-mail and asked to complete a second anonymous survey (follow-up survey) about their current teaching practice in statistics, the perceived impact of the intervention and their beliefs about the value of statistics in the training of secondary students. For the latter, we included three statements, rated on the same five-point Likert scale based on previous scales for value component of attitudes towards statistics (Schau et al., 1995, Estrada, Batanero, \& Fortuny, 2004).

\section{PROGRAM IMPLEMENTATION}

From 2014 to 2017, 565 pre-service teachers participated in seventeen activity-based workshops involving contents and pedagogical strategies about statistics and probability; $66 \%$ of teachers participated in both workshops. Most of the participants were mathematics preservice teachers although some science pre-service teachers joined the workshops, too. The number of pre-service teachers from each institution ranged from 9 to 165 with a median of 30 . 
Most of the participants had some teaching experience at secondary level as part of the teaching practice in their training program.

During the three-year period, the framework and the main activities associated to each workshop were not modified. However, the answers of the participants in the opinion survey and the informal exchange of opinions after every workshop allow us to incorporate some changes in the presentation and the vocabulary in order to adapt the content to the target population. Additionally, as part of the discussion stage in each workshop, both participants and organizers proposed alternatives for the activities performed that included incorporation of technology (internet, simulations, etc.), data acquisition by participants and other options related to the GAISE recommendations (Carver et al., 2016).

The web-site was presented in the workshops and described by folders that were also distributed to other teachers and teacher students to promote the aim of the project, its strategy, and the materials provided by it. Until December 2018, the web-site registered 3061 visits from 757 visitors, mainly from Argentina. Although it is not possible to establish the goal of these visits, it was expected that at least part of them were made by teachers with the purpose to download activities for their classes (see below in the follow-up survey section).

\section{PROGRAM EVALUATION}

\subsection{OPINION SURVEY}

The response rate for the opinion survey (Table 1) ranged between $70-90 \%$ depending on the workshop. Most of the participants (87.2\%) considered that the program contributed to a better understanding of statistical contents. In fact, Question 1 was the question that obtained the highest "strongly agree" rate indicating that participants recognized the importance of the activities involved. In the following, we speak of "agree" if the students judged the statement with partially agree or strongly agree. In this sense, $85.7 \%$ of participants indicated that this program also contributed to improve their attitudes towards statistics (Question 5).

Table 1. Results of the opinion survey (percentage of subjects selecting each answer)

\begin{tabular}{lccccc} 
& $\begin{array}{c}\text { Strongly } \\
\text { disagree }\end{array}$ & $\begin{array}{c}\text { Partially } \\
\text { disagree }\end{array}$ & $\begin{array}{c}\text { Neither agree } \\
\text { nor disagree }\end{array}$ & $\begin{array}{c}\text { Partially } \\
\text { agree }\end{array}$ & $\begin{array}{c}\text { Strongly } \\
\text { agree }\end{array}$ \\
\hline $\begin{array}{l}\text { Q1: The workshop helped me to } \\
\text { improve my understanding of } \\
\text { statistical issues }\end{array}$ & $1.1 \%$ & $1.7 \%$ & $10.0 \%$ & $26.1 \%$ & $61.1 \%$ \\
$\begin{array}{l}\text { Q2: The activities performed in } \\
\text { the workshop are relevant to } \\
\text { teaching statistics at secondary } \\
\text { school }\end{array}$ & $1.1 \%$ & $1.6 \%$ & 16.5 & $34.1 \%$ & $46.7 \%$ \\
$\begin{array}{l}\text { Q3: The activities performed in } \\
\text { the workshop are feasible to } \\
\text { implement in secondary school }\end{array}$ & $1.6 \%$ & $4.9 \%$ & $18.7 \%$ & $36.3 \%$ & $38.5 \%$ \\
$\begin{array}{l}\text { Q4: I would use these activities in } \\
\text { my classes }\end{array}$ & $1.1 \%$ & $2.7 \%$ & $21.4 \%$ & $35.2 \%$ & $39.6 \%$ \\
$\begin{array}{l}\text { Q5: The workshop contributed to } \\
\text { a better attitude towards statistics }\end{array}$ & $1.1 \%$ & $2.2 \%$ & $11.0 \%$ & $32.4 \%$ & $53.3 \%$ \\
\hline
\end{tabular}


Concerning the relevance of the activities for teaching statistics, $81 \%$ of the participants agreed with this aspect (Question 2). However, when the students were asked about the adaptability of the activities to actual teaching in class (Question 3) or if they would implement these activities in their teaching (Question 4), the agreement decreased to $75 \%$ in both cases.

A median of 9 (range $=5-10$ ), and a mean of 8.6 with a standard deviation of 1.1 was obtained for the global qualification of the workshop (measured on a scale of 1 to 10). This rating corroborates that participants showed a great interest and enthusiasm in the activities and the discussion sessions.

In response to the open-ended question, two types of answers were registered: feedback about the workshops and improvement suggestions. Some comments about the workshops were:

"This workshop taught me that statistics is part of daily life."

"The didactical games included in this workshop made me rethink statistical contents in a gaming way, which is accessible for secondary students."

"The methodology proposed leads us to clearly realize the importance of statistical contents for analysing information with a critical stance."

The suggestions for improvement included computer use, additional activities, and shorter activities. The comments made by subjects in this section in addition to the ones made in the discussion session of the workshops allowed us to improve our proposal by taking advantage of their experience in secondary education.

\subsection{FOLLOW-UP SURVEY}

The response rate was low (15\%), which was expected after such a long period of time (2-5 years). $63 \%$ of the respondents claimed to have taught statistics in their classes. Of the remaining 37\%, 41\% were not yet in-service. When they were asked about the role of the workshops for their professional life, $81 \%$ stated that the workshops had helped them to teach statistics to their students. When these participants were encouraged to justify their answer, most of them indicated that workshops brought them the tools required to teach contents in a more didactic way (34\%), and that the workshops had helped them to understand the relevance of the contents for daily life (21\%). On the other hand, $19 \%$ of respondents indicated that their participation in the workshops did not help them to teach statistics contents in their classes. However, the most common justification for this answer (63\%) was that they did not have the opportunity to apply these didactic tools because they were not in-service, or because the contents were not part of their curriculum.

The results of the items measuring the perceived value towards statistics showed very positive attitudes among teachers (Table 2). More than $80 \%$ recognize the worth of statistics in society (Questions 1 and 2), and the need to teach it (Question 3).

Table 2. Follow-up survey (percentage of subjects selecting each answer)

$\begin{array}{lrccc}\text { Strongly } & \begin{array}{r}\text { Partially } \\ \text { disagree }\end{array} & \begin{array}{c}\text { Neither agree } \\ \text { nor disagree }\end{array} & \begin{array}{c}\text { Partially } \\ \text { agree }\end{array} & \begin{array}{c}\text { Strongly } \\ \text { agree }\end{array}\end{array}$

Q1: Statistics is essential for the formation of the future citizen

Q2: Statistics is only useful for those who plan to study at the university

Q3: If I could eliminate any topic from the classes, it would be statistics
$2.2 \%$

$82.4 \%$

$0 \%$

$8.8 \%$

$8.8 \%$

$0 \%$

$80.6 \%$

$0 \%$

$12.9 \%$

$6.5 \%$

$0 \%$ 


\section{DISCUSSION}

Our work was motivated by the diagnosis of the existence of a gap between the educational training of mathematics teachers and the demands on their teaching practice in statistics in Argentinean secondary school. To fill this gap, we developed a pedagogical intervention that consisted in a short training program to teach statistics focused on activity-based learning to improve pre-service teachers' skills to teach statistics at the secondary level and to address students' learning problems.

The results of the opinion survey suggest an improvement of the self-perceived statistical reasoning and thinking in pre-service teachers, as well as their self-perceived attitudes towards statistics. In relation to the provided resources for teaching statistics, the survey showed that activities focused on statistical reasoning and real-data rather than on calculations or procedural aspects and were judged by pre-service teachers as appropriate and feasible to be implemented in the classroom for teaching statistics in the secondary school; most of them showed a proactive attitude towards using them.

According to the results of the follow-up survey, mathematics teachers who attended our workshops seem to recognize the value of statistics in the training of their students, both for personal and social life. Although we cannot certainly attribute these positive attitudes to our training program, the scores obtained are high compared to those of other pre- and in-service teacher surveys (Estrada, Batanero, \& Lancaster, 2011). They also believe that the workshops have helped them to teach statistics in their classes. Finally, the follow-up survey showed that most teachers are teaching statistics, which is remarkable compared to the usual practice in the secondary school in Argentina. Putting them together, these results suggest that the intervention has contributed to bringing statistics to the secondary school.

This study has several limitations that should be acknowledged. First, it was not possible to formally evaluate the impact of the intervention, using validated questionnaires, pre-post changes in the teachers' statistical literacy, reasoning and thinking scale, nor their attitudes towards statistics. The measurement of the perceived value towards statistics in the follow-up survey can be considered only as a proxy of the value component in the attitudes-towardsstatistics construct, as it was limited to only three questions. Second, the follow-up survey had a low response rate, limiting the extent to which the findings can be generalized.

Despite the limitations of this study, the evidence suggests that our training program helped mathematics teachers feel more confident to teach statistics in their classes. We cannot elucidate whether an improvement in their attitudes towards statistics, or in their statistical literacy, reasoning and thinking, or the access to resources for teaching statistics developing statistical thinking, are, alone or together, responsible for the findings.

Though our work had the purpose to attend a local issue, it is also a concern in other countries and contexts (Batanero \& Díaz, 2010; Meletiou, 2007). Additionally, our intervention contributed to implement and support conceptual understanding of statistics and other recommendations made by de ASA (Carver et al., 2016) in Argentina.

Mathematics pre-service and in-service teachers do neither have many resources nor the opportunities to develop a deep understanding of statistics and the confidence to teach the curriculum topics in secondary school as compared to other areas of mathematics. An additional barrier for Spanish-speaking teachers (as is the case in Argentina) is that many pedagogical resources are available only in English. This applies for materials on the Internet, academic articles in the literature, pedagogical books, and textbooks focusing on statistical reasoning. As previously mentioned, most mathematics textbooks used in secondary schools in Argentina do not help to reverse this situation. In this sense, our web-site is currently acting as a platform for disseminating excellent textbooks with an innovative approach (Batanero, 2001; Kelmansky, 2009), links to other web-sites (e.g. http://estadis.net/recursosestadisticos/), and academic articles in Spanish. Based on the number of visits, the web-site seems to be a useful platform to spread resources. We speculate that there could be also dissemination of information from teachers who attended our workshops to some colleagues but we have no formal evidence on 
that. In the future, we plan to provide a free-access compilation of activities, both our own and from others, also translated from English, which teachers can directly use in their classes.

Effecting a change in the way statistics is taught, strongly depends on teachers' attitudes and the training they receive. These factors play a critical role in the selection of the contents and the way they are taught in the classroom (Estrada, Batanero, \& Lancaster, 2011). This intervention was focused on pre-service teachers as they are more accessible, more predisposed to revise their pre-concepts and incorporate new strategies for statistics teaching, and more susceptible to achieve attitudinal change than in-service teachers. Moreover, the multiplier effect should be greater, as the impact caused on the participants will be then translated to their students in the future for many years.

Finally, workshops cannot be an appropriate tool to broaden the reception of new techniques and didactical approaches to a wider audience. If the approach we propose here implies an effective tool to enhance positive attitudes to teach and learn statistics, then the program needs to be included in the formal curricula for both future and current teachers.

Despite our contribution, there is a need to continue and deepen the training of pre-service as well as in-service teachers. Local initiatives like ours may have limited scope. As statistics pedagogy is not part of the regular curriculum in teacher training, this intervention serves only as a complementary support. For the future, mathematics-teacher education programs have to be revised to put a greater emphasis on statistics reasoning and fundamental statistical ideas. For example, the Statistics Education of Teachers program in the US (Franklin et al., 2015) proposes two statistics courses in teacher training for mathematics teachers at secondary level instead of only one as it is offered currently. The training would include an introductory course about statistical content knowledge similar to the existing one plus some more contents while the second course could focus on developing teachers' pedagogical content knowledge by providing strategies and learning paths for teaching statistical concepts. This second course would also integrate appropriate technology into the instruction, make connections across the curriculum, and offer ways of assessing statistical understanding. This is a way to guarantee a large-scale impact on statistics teaching at the secondary level, in order to promote statistically literate citizens.

\section{ACKNOWLEDGEMENTS}

This project was supported by funding from the University of Buenos Aires (Exactas con la Sociedad 4 y 5, UBANEX 2015). We thank students, teachers, and coordinators of the teachertraining programmes who participated in this project. We would also like to thank members of the Faculty of Exact and Natural Sciences (University of Buenos Aires) who were involved in the coordination and administration of the workshops. We are grateful to Victor Antuña Contal for his comments and his concern about the progress of this article.

\section{REFERENCES}

Batanero, C. (2001). Didáctica de la Estadística. Granada: Universidad de Granada.

Batanero, C., \& Díaz, C. (2010). Training teachers to teach statistics: What can we learn from research? Statistique et Enseignement, 1(1), 5-20.

[Online: statistique-et-enseignement.fr/article/view/3]

Begg, A., Pfannkuch, M., Camden, M., Hughes, P., Noble, A., \& Wild, C. (2004). The school statistics curriculum: Statistics and probability education literature review. Auckland: University of Auckland.

Ben-Zvi, D, \& Garfield, J. (2004). Statistical literacy, reasoning, and thinking: Goals, definitions, and challenges. In The challenge of developing statistical literacy, reasoning and thinking (pp. 3-15). Dordrecht: Springer. 
Ben-Zvi, D., \& Makar, K. (Eds.) (2016). International perspectives on the teaching and learning of statistics. In Ben-Zvi, D., \& Makar, K. (Eds.), The teaching and learning of statistics (pp. 1-10). Cham, Switzerland: Springer International.

Borovenik, M. (2016). Probabilistic thinking and probability literacy in the context of risk. Pensamento probabilistico e alfabetização em probabilidade no contexto do risco. Educação Matemática Pesquisa, 18(3), 1491-1516.

Burrill, G., \& Biehler, R. (2011). Fundamental statistical ideas in the school curriculum and in training teachers. In C. Batanero, G. Burrill, \& C. Reading (Eds.), Statistics in school mathematics. Challenges for teaching and teacher education (pp. 57-69). Dordrecht, New York: Springer.

Callingham, R. \& Watson, J. (2011). Measuring levels of statistical pedagogical content knowledge. In C. Batanero, G. Burrill, \& C. Reading (Eds.), Statistics in school mathematics. Challenges for teaching and teacher education (pp. 283-293). Dordrecht, New York: Springer.

Carver, R., Everson, M., Gabrosek, J., Horton, N., Lock, R., Mocko, M., Rossman, A., Rowell, G. H., Velleman, P., Witmer, J., \& Wood, B. (2016). Guidelines for assessment and instruction in statistics education (GAISE) College report 2016. Alexandria, VA: American Statistical Association. [Online: www.amstat.org/education/gaise]

Estrada, A., Batanero, C., \& Fortuny, J. M. (2004). Un estudio sobre conocimientos de estadística elemental de profesores en formación. Educación matemática, 16(1), 89-111.

Estrada, A., Batanero, C., \& Lancaster, S. (2011). Teachers attitudes towards statistics. In C. Batanero, G. Burrill, \& C. Reading (Eds.), Statistics in school mathematics. Challenges for teaching and teacher education (pp. 163-174). Dordrecht, New York: Springer.

Estrada, A., Bernabeu, C. B., \& Aymemí, J. M. F. (2004). Un estudio comparado de las actitudes hacia la estadística en profesores en formación y en ejercicio. Enseñanza de Las Ciencias: Revista de Investigación Y Experiencias Didácticas, 22(2), 263-273.

Fabrizio, M., López, M. V., \& Plencovich, M. C. (2011). Statistics in teacher training colleges in Buenos Aires, Argentina: Assessment and challenges. In P. L. do Nascimento (Ed.), Proceedings of the 56th Session of the International Statistics Institute (pp. 4630

Franklin, C., Bargagliotti, A., Case, C., Kader, G., Scheaffer, R., \& Spangler, D. (2015). Statistical education of teachers. Alexandria, VA: American Statistical Association.

[Online: www.amstat.org/ASA/Publications/Education-Publication.aspx?hkey=9aac4df0a579-4a3e-bef9-e2938249c084]

Franklin, C., Kader, G., Mewborn, D., Moreno, J., Peck, R., Perry, M., \& Scheaffer, R. (2007). Guidelines and Assessment for Instruction in Statistics Education (GAISE) Report: A PreK-12 Curriculum Framework. Alexandria, VA: American Statistical Association.

Garfield, J., \& Ben-Zvi, D. (2004). Research on statistical literacy, reasoning, and thinking: Issues, challenges, and implications. In Ben-Zvi, \& Garfield (Eds.), The challenge of developing statistical literacy, reasoning and thinking (pp. 397-409). Springer.

Groth, R. E. (2013). Characterizing key developmental understandings and pedagogically powerful ideas within a statistical knowledge for teaching framework. Mathematical Thinking and Learning, 15(2), 121-145.

Kelmansky, D. M. (2009). Estadística para todos: estrategias de pensamiento y herramientas para la solución de problemas. Ministerio de Educación, Instituto Nacional de Educación Tecnológica.

Kucukbeyaz, D., \& Batto, M. (2012, October). El desarrollo de métodos para la enseñanza de la Estadística en la educación media. X Congreso Latinoamericano de Sociedades de Estadística. 16-19 October 2012, Córdoba, Argentina.

Lancaster, S. (2008). A study of preservice teachers' attitudes toward their role as students of statistics and implications for future professional development in statistics. In C. Batanero, G. Burrill, C. Reading, \& A. Rossman (Eds.), Proceedings of the IASE Roundtable Conference: Challenges for Teaching and Teacher Education. Joint ICMI/IASE Study. Online: iase-web.org/Conference_Proceedings.php?p=Joint_ICMI-IASE_Study_2008] 
Lovett, J. N., \& Lee, H. S. (2017). New standards require teaching more statistics: Are preservice secondary mathematics teachers ready? Journal of Teacher Education, 68(3), 299311. [Online: journals.sagepub.com/doi/full/10.1177/0022487117697918]

Meletiou, M. (2007). The formalist mathematical tradition as an obstacle to stochastical reasoning. In K. François, J. P. van Bendegem (Eds.), Philosophical dimensions in mathematics education. Mathematics Education Library (pp. 131-155). New York: Springer.

Ministerio Educación (1993). Ley Federal de Educación. Ley No. 24.195. [Online: servicios.infoleg.gob.ar/infolegInternet/anexos/15000-19999/17009/texact.htm]

Ministerio de Educación, C. F. de E. (2011). Núcleos de aprendizaje prioritarios. Matemática. Argentina. [Online: www.educ.ar/recursos/150199/coleccion-ncleos-de-aprendizajeprioritarios-nap?from $=51$ ?from $=51]$

Pfannkuch, M., \& Ben-Zvi, D. (2011). Developing teachers statistical thinking. In C. Batanero, G. Burrill, \& C. Reading (Eds.), Statistics in school mathematics. Challenges for teaching and teacher education (pp. 323-333). Dordrecht, New York: Springer.

Pinto, J., Tauber, L., Zapata-Cardona, L., Albert, A., Ruiz, B., \& Mafokozi, J. (2017). Alfabetización estadística en educación superior. Acta Latinoamericana de Matemática Educativa (pp. 227-235). México, DF: Comité Latinoamericano des Matemática Educativa.

Pomilio, C. J., Miño, M. H., Brignone, N. F., García Facal, G., Telesnicki, M. C., Fass, M., Filloy, J., Cueto, G., Soledad Fernandez, M. \& Perez, A. (2016). Análisis de actividades sobre estadística descriptiva en libros de educación media: ¿Qué se pretende que los estudiantes aprendan? [Analysis of activities concerning to statistics in high school textbooks: What do we want students to learn?] Edução Matemática Pesquisa, 18(3), 13451364.

Schau, C., Stevens, J., Dauphinee, T. L., \& Del Vecchio, A. (1995). The development and validation of the Survey of Attitudes toward Statistics. Educational and Psychological Measurement, 55, 868-875.

Tauber, L. M., Cravero, M., \& Redondo, Y. (2013). Evaluación de errores de profesores de matemática en tareas de alfabetización estadística y de razonamiento estadístico. Probabilidad Condicionada: Revista de Didáctica de La Estadística, (1), 273-284.

Wild, C. J., \& Pfannkuch, M. (1999). Statistical thinking in empirical enquiry (with discussion). International Statistical Review, 67(3), 223-265.

[Online: onlinelibrary.wiley.com/doi/abs/10.1111/j.1751-5823.1999.tb00442.x]

ADRIANA PÉREZ

Grupo de Bioestadística Aplicada

Departamento de Ecología, Genética y Evolución

Intendente Güiraldes 2160, Ciudad Universitaria, PB II

C1428EHA Ciudad, Autónoma de Buenos Aires

Argentina 